NBER WORKING PAPER SERIES

EXCHANGE-RATE UNIONS

AND THE VOLATILITY OF THE DOLLAR

Richard C. Marston

Working Paper No. 492

NATIONAL BUREAU OF ECONOMIC RESEARCH

1050 Massachusetts Avenue

Cambridge MA 02138

June 1980

The author is indebted to Richard Herring, Stephen Meyer, and seminar participants at the University of Pennsylvania, Princeton University, and the NBER's Summer Institute for their helpful comments and suggestions. Financial support for the Rodney White Center for Financial Research and the NBER is gratefully acknowledged. The research reported here is part of the NBER's research program in International Studies. Any opinions expressed are those of the author and not those of the National Bureau of Economic Research. 


\title{
EXCHANGE-RATE UNIONS AND THE VOLATILITY OF THE DOLIAR
}

\author{
Abstract
}

This study analyzes why formation of an exchange-rate union, such as the newly-established European Monetary System, can be harmful to the interests of some member countries. The framework provided for analyzing behavior in the union is a three-country model which combines an asset market determination of exchange rates with a price sector emphasizing wage indexation behavior and price competitiveness between countries. The three countries consist of two members of the union as well as a nonmember country (the United States), allowing the study to investigate trade and financial relationships within and outside the union.

The study examines how each country's exchange rates and prices respond to stochastic disturbances of several types, of which the most important is a capital account disturbance directly affecting one member's financial market (originating, for example, in shifts between U.S. securities and those of one member country). The analysis shows that the effects of the union on each member country depends upon (1) the source of those economic disturbances which give rise to fluctuations in exchange rates, (2) the share of trade between members of the union, (3) the degree of integration between the financial markets of the member countries, and (4) the responsiveness of domestic wages and prices to changes in exchange rates.

The exchange-rate union fixes the cross exchange rate between member currencies, thereby preventing disturbances from affecting this key exchange rate. In doing so, however, the union may actually increase the variability of prices in the economy of one member country. The outcome depends critically upon the degree of financial integration between the two member countries in the absence of the union. The importance of another factor, domestic price responsiveness, is brought out clearly by comparing the alternative extremes of no price adjustment and full price adjustment to exchange rate changes. Price behavior interacts in an interesting way with financial integration to determine the potential gains or losses of each country in joining the union.

Richard C. Marston The Wharton School University of Pennsylvania Philadelphia, PA 19104 
In the current period of floating exchange rates, some countries have chosen to tie their exchange rates together in a joint float against the U.S. dollar, forming exchange-rate unions within a system of floating exchange rates. The most prominent of these unions is the European Monetary System -a union fixing exchange rates between European currencies. ${ }^{1}$ The EMS, as well as unions elsewhere, represent an important departure from exchange rate flexibility with effects on union and nonunion countries that need to be examined.

The reasons for forming a union vary widely, but one common concern is about how exchange rate fluctuations affect trading and other economic relationships between potential members of the union. Countries in exchangerate unions often conduct much of their trade with other countries in the union; in the absence of a union, fluctuations in exchange rates disrupt trade between the member countries and lead to significant changes in their general price levels. For example, recent exchange rate crises have involved major fluctuations in the Deutsche Mark price of the dollar; to the extent that other European currencies have not followed the DM's movements, bilateral rates within Europe have been affected. Proponents of exchangerate unions claim that the fixing of bilateral rates will minimize the disruptive effects of such disturbances.

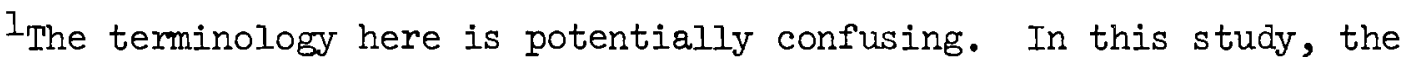
term exchange-rate union refers to an arrangement in which member countries of the union maintain fixed exchange rates between member currencies, but with each country retaining its own central bank with control over its national monetary policy. This limited type of union, which Corden (1972, p. 3) calls a "pseudo-exchange-rate union," is to be distinguished from a "complete exchange rate union," or monetary union, with a single central bank and a union-wide currency.
} 
This paper provides a framework for analyzing the effects of an exchangerate union. The paper shows that the desirability of a union depends upon several key factors:

1. The trade pattern of the countries in the union. What is important is not just the general openness of the economy, as in McKinnon (1963), but the share of trade between potential member countries relative to trade with the rest of the world. 2

2. The source of those economic disturbances which give rise to fluctuations in exchange rates. Chief among these are financial disturbances which affect one member country's financial market more than another, with the volatility in the dollar exchange rate of that country leading to changes in bilateral rates in the absence of a union.

3. The degree of integration between the financial markets of the member countries. This paper shows how financial integration facilitates intraunion adjustment, not through the long-term financing of deficits within a union, as in Ingram (1973), but through market adjustments in the absence of a union.

4. The degree of price responsiveness to changes in exchange rates, a point emphasized earlier by Corden (1972). The model to be developed will include a labor market with partial or full wage indexation and a goods market with pricing behavior allowing foreign prices to have a direct impact on domestic prices and with demand behavior reflecting either imperfect or perfect substitution between foreign and domestic goods.

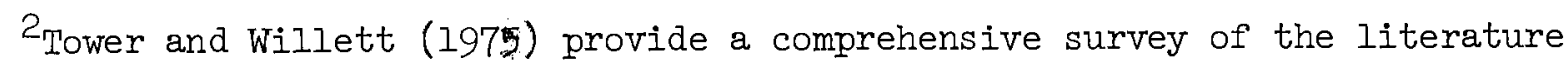
on optimum currency areas which examines the conditions necessary for successful exchange-rate or monetary unions; McKinnon (1963) and Mundell (1961) are two early contributions to this literature. Among other studies of unions are Allen (1976), Corden (1972), and Ingram (1973), the latter two specifically dealing with a European monetary union. Thygesen (1979) describes the European Monetary System. 
Section I of the paper develops a financial model for two types of exchange-rate regimes: fully flexible exchange rates and an exchange-rate union floating against the dollar. As in the monetary approach to the exchange rate, the transactions demand for money is a key ingredient in the short-mun determination of exchange rates. But the financial model also includes interest-bearing assets which are imperfect substitutes for one another, and allows for the capital-gains effects of exchange rate changes. The financial model will be used to analyze the effects of a union in a world in which wages and the prices of domestic goods are exogenous.

In Section II of the paper, the adjustment of domestic prices to foreign prices and exchange rates is traced directly to behavior in the labor market and pricing behavior in the goods market. The wage and price equations, together with the asset equations specified in Section I, are used to analyze several types of economic disturbances, among them fluctuations in world prices and financial disturbances. In Section III of the paper, the expanded model is used to compare experience under flexible rates with that in an exchange-rate union. The analysis shows that wage indexation plays a key role in determining whether an exchange-rate union can achieve its objectives.

I. Financial Behavior in an Exchange-Rate Union

To investigate the relationship among exchange rates, interest rates and prices in an exchange-rate union, a three-country model of financial behavior under flexible exchange rates is introduced. ${ }^{3}$ The three countries

3 The underlying model of financial behavior is similar to those of Brans on (1976), Girton and Henders on (1976), and Herring and Marston (1977). 
include two potential members of the exchange-rate union, countries 1 and 2 , as well as a third country called the United States. Each country has its own currency; country I's currency is called the franc, country 2's the mark, and the U.S. currency the dollar. The exchange rates for these currencies are as follows:

$$
\begin{aligned}
& \mathrm{x}^{1} \text { : franc price of the dollar, } \\
& \mathrm{x}^{2} \text { : mark price of the dollar, and } \\
& \mathrm{x}^{12} \text { : franc price of the mark. }
\end{aligned}
$$

Triangular arbitrage ensures that the cross exchange rate between the currencies of countries 1 and 2 are linked to the respective dollar exchange rates, $\mathrm{X}^{12}=\mathrm{X}^{1} / \mathrm{X}^{2}$. In an exchange-rate union, this cross exchange rate is fixed by foreign exchange intervention as described below.

Each member country has two financial assets, money $\left(\mathrm{M}^{i}\right)$ and a home bond $\left(H^{i}\right)$. The United States issues a dollar-denominated bond $(F)$; the two member countries are assumed to be too small to influence the interest rate paid on this dollar bond $\left(r^{3}\right)$. The public in each member country is assumed to hold four different assets: domestic money, bonds denominated in domestic currency (and issued by the domestic government), and bonds denominated in each of the other currencies, a range of assets permitting diversification of portfolios across the three currencies. (See Table 1 for the balance sheets of the public and the monetary authorities of countries 1 and 2). Domestic money is issued by the monetary authority of that country, which in turn holds as assets domestic bonds and three types of foreign exchange reserves: dollar bonds and the bonds and money of the other potential member of the union. 
Table 1

Sectoral Balance Sheets

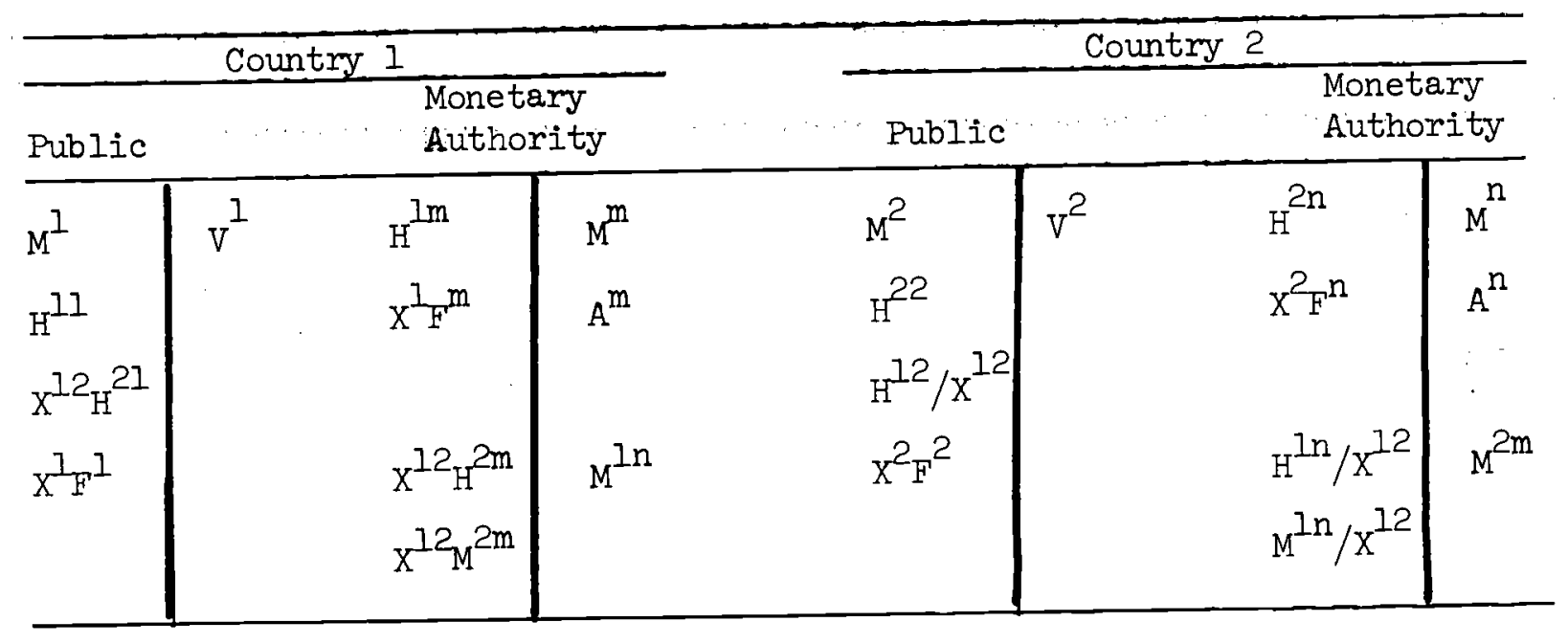

Notes: The superscript $m$ denotes the monetary authority of country $1, n$ the monetary authority of country 2. The public of country 1 holds its wealth $\left(V^{I}\right)$ in the form of domestic money $\left(M^{1}\right)$, domestic bonds $\left(H^{1}\right)$, country $2^{\prime} s$ bonds $\left(H^{21}\right.$, which enters the balance sheet at the exchange rate $\left.\mathrm{X}^{12}\right)$, and foreign bonds $\left(F^{1}\right.$, with exchange rate $\left.X^{1}\right)$. The monetary authority of country 1 holds as assets home bonds $\left(H^{I m}\right)$, dollar bonds $\left(X^{1} F^{m}\right)$, as well as the bonds $\left(\mathrm{H}^{2 \mathrm{~m}}\right)$ and money $\left(\mathrm{M}^{2 \mathrm{~m}}\right)$ of country 2 with exchange rate $\mathrm{X}^{12}$. Its liabilities consist of money held by the domestic public $\left(\mathrm{M}^{\mathrm{m}}\right)$ and by the monetary authority of country $2\left(\mathrm{M}^{\mathrm{In}}\right)$, plus a balancing item $\left(\mathrm{A}^{\mathrm{m}}\right)$ which offsets changes in exchange rates in the monetary authorities' balance sheets. The balance sheets of country 2 are explained analogously. 
The transactions demand for money plays a central role in determining prices and the exchange rate. The demand for money is assumed to depend positively on the ratio of nominal output (Py) to nominal wealth (V), while the demand for home and foreign bonds depends negatively on this ratio. Holdings of each asset are expressed as a fraction of total wealth, so that asset demands are homogeneous of degree one in Py and V. 4 (See Table 2.)

The bonds of countries $I$ and 2 pay interest rates of $r^{l}$ and $r^{2}$, respectively; the total expected return for the $i^{\text {th }}$ country investor includes the expected change in the exchange rate $z^{i}=\sqrt{E}\left(x^{i}\right)-x^{i} J / x^{i}$, for $x^{i}=x^{I}$, $\mathrm{x}^{2}, \mathrm{x}^{12}$. The asset demands of the public are assumed to be gross substitutes; that is, asset demands are positively related to the own interest rate and negatively related to the returns on other assets. Each asset demand includes a stochastic element ( $u^{\mathrm{mi}}, u^{\mathrm{hij}}$, or $u^{\mathrm{fi}}$ ), the properties of which will be specified below. The equilibrium conditions for the money and bond markets are set out in Table 2 .

Because of the inherent complexity of the three country model, several additional assumptions are adopted to simplify the analysis:

1. Countries $I$ and 2 are assumed to have "identical" financial behavior. The initial portfolios of the two countries are identical in the sense that the public of each country holds the same amount of its own domestic money and bonds, dollar bonds, and the bonds of the other country; one country's initial portfolio is thus the mirror image of the other country's portfolio. 5

Hor a similar formulation, see Henderson (1977).

5 The assumption of identical behavior does not require that country 1 hold equal amounts of its initial wealth in country 1 and country 2 bonds, but only that its initial holdings of country 1 (2) bonds be equal to country 2's initial holdings of country 2 (1) bonds. 


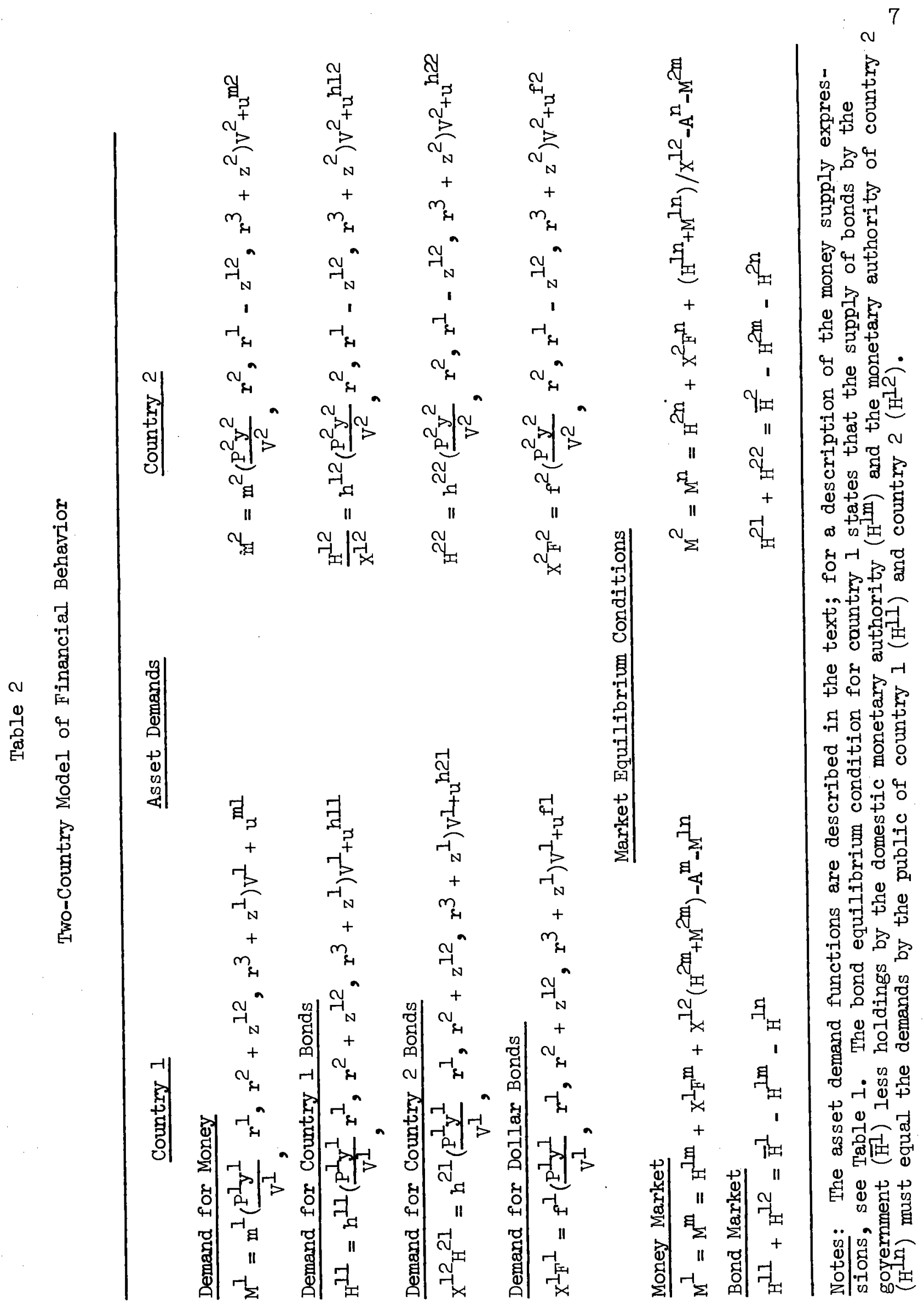


The asset demands of the two countries, moreover, are equally sensitive to changes in own interest returns, cross returns, output or wealth. Finally, the initial levels of output are assumed to be equal in the two countries, as are the initial levels of wealth. This assumption of identical behavior rules out the effects of size or other asymmetries within the union, an interesting topic for later analysis.

2. The elasticity of the demand for money with respect to transactions is assumed to be unity. With the specification above, this assumption implies that a rise in nominal output with wealth constant will increase the demand for money proportionately, while a rise in wealth with output constant will leave unchanged the demand for money. 6 The demand for money is also assumed to be more sensitive to an increase in the home interest rate than to increases in the interest rates on bonds denominated in other currencies.

3. The disturbances to be analyzed below are all serially uncorrelated with mean zero. Assuming that expectations are rational, then $\mathrm{z}^{\mathrm{i}}$, the expected change in the exchange rate, must equal zero for all exchange rates. More complex types of disturbances would be interesting to study, but would complicate the analys is significantly.

\section{A. Behavior Under Flexible Exchange Rates}

To study the response of financial variables to stochastic disturbances, the asset demands are linearized around the equilibrium values of the exchange rates $\left(x_{0}^{i}\right)$, interest rates $\left(r_{0}^{i}\right)$, domestic prices and output $\left(\mathrm{P}_{0}^{i}, \mathrm{y}_{0}^{i}\right)$,

$6_{\text {This assumption simplifies the analysis of prices and exchange rates }}$ since increases in prices lead to proportionate increases in the demand for money, while increases in exchange rates affect the demand for money only to the extent to which prices or interest returns change. 
as well as the disturbances $\left(u_{0}^{m i}=u_{0}^{h i j}=u_{0}^{f i}=0\right)$. For convenience, the initial values of all prices and exchange rates are set equal to unity.

The four equilibrium conditions in Table 2 determine four financial variables $\left(r^{1}, r^{2}, x^{1}, x^{2}\right)$ as functions of prices, output, the disturbances, as well as other variables. In the analysis below, the relationship between exchange rates and prices will be of major interest. For this reason, the four equations are solved for the two exchange rates $\left(x^{i}\right)$ as follows:

$$
\left[\begin{array}{cc}
\mathrm{H}_{\mathrm{x} 1}^{1} & \mathrm{H}_{\mathrm{x} 2}^{1} \\
\mathrm{H}_{\mathrm{x} 1}^{2} & \mathrm{H}_{\mathrm{x} 2}^{2}
\end{array}\right]\left[\begin{array}{c}
\left(\mathrm{x}^{1}-\mathrm{x}_{0}^{1}\right) \\
\left(\mathrm{x}^{2}-\mathrm{x}_{0}^{2}\right)
\end{array}\right]=\left[\begin{array}{l}
J^{11}\left(\mathrm{P}^{1} \mathrm{y}^{1}-\mathrm{P}_{0}^{1} \mathrm{y}_{0}^{1}\right)+J^{12}\left(\mathrm{P}^{2} \mathrm{y}^{2}-\mathrm{P}_{0}^{2} \mathrm{y}_{0}^{2}\right)-\left(\mathrm{u}^{\mathrm{hl}}-\mathrm{u}_{0}^{\mathrm{hl}}\right) \\
J^{21}\left(\mathrm{P}^{1} \mathrm{y}^{1}-\mathrm{P}_{0}^{1} \mathrm{y}_{0}^{1}\right)+\mathrm{J}^{22}\left(\mathrm{P}^{2} \mathrm{y}^{2}-\mathrm{P}_{0}^{2} \mathrm{y}_{0}^{2}\right)-\left(\mathrm{u}^{\mathrm{h} 2}-\mathrm{u}_{0}^{\mathrm{h} 2}\right)
\end{array}\right]
$$

where $H_{x i}^{i}, J^{i j}>0, H_{x j}^{i}, J^{i i}<0$, and $u^{\text {hi }}=u^{\text {hil }}+u^{\text {hi2 }}{ }^{7}$ Increases in the level of transactions in either country 1 or 2 lead to changes in the excess demand for $\mathrm{H}^{l}$ and $\mathrm{H}^{2}$; the coefficients $\mathrm{J}^{i i}$ and $\mathrm{J}^{i j}$ reflect the direct impact of higher transactions on the demand for money and bonds, as well as the indirect impact working through changes in interest rates. Increases in exchange rates similarly induce changes in the excess demand for each bond with the coefficients $\mathrm{H}_{\mathrm{xi}}^{i}$ and $\mathrm{H}_{\mathrm{xj}}^{i}$ reflecting the impact of changes in exchange rates on these asset demands.

To understand the adjustment of interest rates and exchange rates in the two countries, consider the effects of an increase in the price of country $2^{\prime} \mathrm{s}$ goods $\left(\mathrm{P}^{2}\right)$. The higher price level leads to an increase in country $2^{\prime}$ 's interest rate. An excess demand for $\mathrm{H}^{2}$ and excess supply of $\mathrm{H}^{1}$ thereby develops, with changes proportional to the coefficients $\mathrm{J}^{22}$ and $\mathrm{J}^{12}$, respectively. To restore equilibrium to the $\mathrm{H}^{2}$ market, the mark must

7 The explicit expressions for these coefficients are given in the appendix. 
appreciate. The mark price of the dollar, $x^{2}$, must fall with the magnitude of the appreciation dependent upon how sensitive is the demand for $\mathrm{H}^{2}$ to changes in $\mathrm{X}^{2}$ as reflected in the coefficient, $\mathrm{H}_{\mathrm{x} 2}^{2}$. Similarly, the mark must appreciate relative to the franc; that is, the franc price of the mark, $\mathrm{x}^{12}$, must rise.

The impact on $\mathrm{X}^{1}$ of a rise in $\mathrm{P}^{2}$ is not as straightforward. $\mathrm{X}^{1}$ and $\mathrm{X}^{2}$ together must adjust so as to increase the demand for country I's bonds. But it is possible for the demand for $\mathrm{H}^{1}$ to increase even when the franc appreciates relative to the dollar ( $x^{1}$ falls). To examine this possibility, the excess demand for $\mathrm{H}^{\mathcal{I}}$ due to changes in exchange rates is rewritten as a function of the two franc exchange rates ${ }^{8}$ (where both coefficients are positive: ${ }^{9}$

$$
\left(\mathrm{H}_{\mathrm{x} 1}^{1}+\mathrm{H}_{\mathrm{x} 2}^{1}\right)\left(\mathrm{x}^{1}-\mathrm{x}_{0}^{1}\right)+\left(-\mathrm{H}_{\mathrm{x} 2}^{1}\right)\left(\mathrm{x}^{12}-\mathrm{x}_{0}^{12}\right)
$$

Since the franc price of the mark $\left(x^{12}\right)$ necessarily rises, the excess demand for $\mathrm{H}^{1}$ can rise even when $\mathrm{X}^{1}$ falls if this demand is particularly sensitive to $\mathrm{X}^{12}$ so that the coefficient $\left(-\mathrm{H}_{\mathrm{x} 2}^{\mathrm{I}}\right)$ is large relative to $\left(\mathrm{H}_{\mathrm{x} 1}^{1}+\mathrm{H}_{\mathrm{x} 2}^{\perp}\right)$. Otherwise, $x^{1}$ will depreciate along with $x^{12}$.

The two coefficients, $\left(\mathrm{H}_{\mathrm{x}]}^{1}+\mathrm{H}_{\mathrm{x} 2}^{1}\right)$ and $\left(-\mathrm{H}_{\mathrm{x} 2}^{1}\right)$, reflect the degree of financial integration among the three countries. The second coefficient is large relative to the first when the public of country 1 (2) primarily holds the bonds of country 2 (1) rather than dollar bonds. In this case of a high degree of financial integration between the member countries, a small change

$8\left(x^{12}-x_{0}^{12}\right)$ is approximately equal to $\left(x^{1}-x_{0}^{1}\right)-\left(x^{2}-x_{0}^{2}\right)$ for small discrete changes around $\mathrm{x}_{0}^{1}=\mathrm{x}_{0}^{2}=\mathrm{x}_{0}^{12}=1$. $\mathrm{H}_{\mathrm{x} 2}^{1}<0$

9t can be readily shown that $\left(\mathrm{H}_{\mathrm{x} 1}^{1}+\mathrm{H}_{\mathrm{x} 2}^{1}\right)>0$, while as previously noted, 
in $\mathrm{x}^{12}$ has a substantial effect on the excess demand for country I's bond. In the opposite case where the public in each member country primarily holds dollar bonds rather than the bonds of the other member country, the first coefficient is larger. Then a small change in $\mathrm{x}^{1}$ has a substantial effect on the excess demand for country I's bond. 10

When the equations in (1) are solved for the two dollar exchange rates, the result is the two equation system:

$$
\left[\begin{array}{l}
\left(\mathrm{X}^{1}-\mathrm{x}_{0}^{1}\right) \\
\left(\mathrm{X}^{2}-\mathrm{x}_{0}^{2}\right)
\end{array}\right]=\left[\begin{array}{ll}
\mathrm{A}^{11} & \mathrm{~A}^{12} \\
\mathrm{~A}^{21} & \mathrm{~A}^{22}
\end{array}\right]\left[\begin{array}{l}
\left(\mathrm{P}^{1} \mathrm{y}^{1}-\mathrm{P}_{0}^{1} \mathrm{y}_{0}^{1}\right) \\
\left(\mathrm{P}^{2} \mathrm{y}^{2}-\mathrm{P}_{0}^{2} \mathrm{y}_{0}^{2}\right)
\end{array}\right]+\left[\begin{array}{cc}
-\mathrm{H}_{\mathrm{x} 2}^{2} & \mathrm{H}_{\mathrm{x} 2}^{1} \\
\mathrm{H}_{\mathrm{xl}}^{2}-\mathrm{H}_{\mathrm{xl}}^{1}
\end{array}\right]\left[\begin{array}{l}
\left(\mathrm{u}^{\mathrm{hl}}-\mathrm{u}_{0}^{\mathrm{hl}}\right) / \mathrm{A} \\
\left(\mathrm{u}^{\mathrm{h} 2}-\mathrm{u}_{0}^{\mathrm{h} 2}\right) / \mathrm{A}
\end{array}\right]
$$

where $\mathrm{A}^{1 I}=\left(\mathrm{H}_{\mathrm{x} 2}^{2} \mathrm{~J}^{1 I}-\mathrm{H}_{\mathrm{x} 2}^{\mathrm{I}} \mathrm{J}^{2 \mathrm{I}}\right) / \mathrm{A}<0$,

$$
\begin{aligned}
& A^{12}=\left(H_{x 2}^{2} J^{12}-H_{x 2}^{1} J^{22}\right) / A \gtrless 0, \\
& A^{22}=A^{11}, A^{21}=A^{12}, A=\left(H_{x 1}^{1} H_{x 2}^{2}-H_{x 2}^{1} \frac{H_{x 1}^{2}}{2}\right) .
\end{aligned}
$$

The coefficients $A^{i i}$ and $A^{i j}$ summarize the all-important impact of prices on exchange rates. As the previous discussion indicated, a rise in the price of country 2's goods must lead to a fall in the mark price of the dollar, $X^{2}$, so $A^{22}$ must be negative. Since the financial sectors of countries 1 and 2 are assumed to be identical, the impact of a rise in $\mathrm{P}^{1}$ on $\mathrm{X}^{1}$ must also be negative $\left(A^{11}=A^{22}\right)$. In response to a rise in $P^{2}$, however, the franc price of the dollar, $\mathrm{x}^{1}$, can either rise or fall, so $\mathrm{A}^{12}$ can be positive or negative. The same indeterminancy pertains to $\mathrm{A}^{21}$.

The relationship between the price of a country's goods and its dollar exchange rate is illustrated for country 1 in Figure 1. The curve labelled

${ }^{10}$ Although this discussion has centered on the coefficients in the equation for $\mathrm{H}^{\mathrm{l}}$, the coefficients in the $\mathrm{H}^{2}$ equation can be similarly compared. 


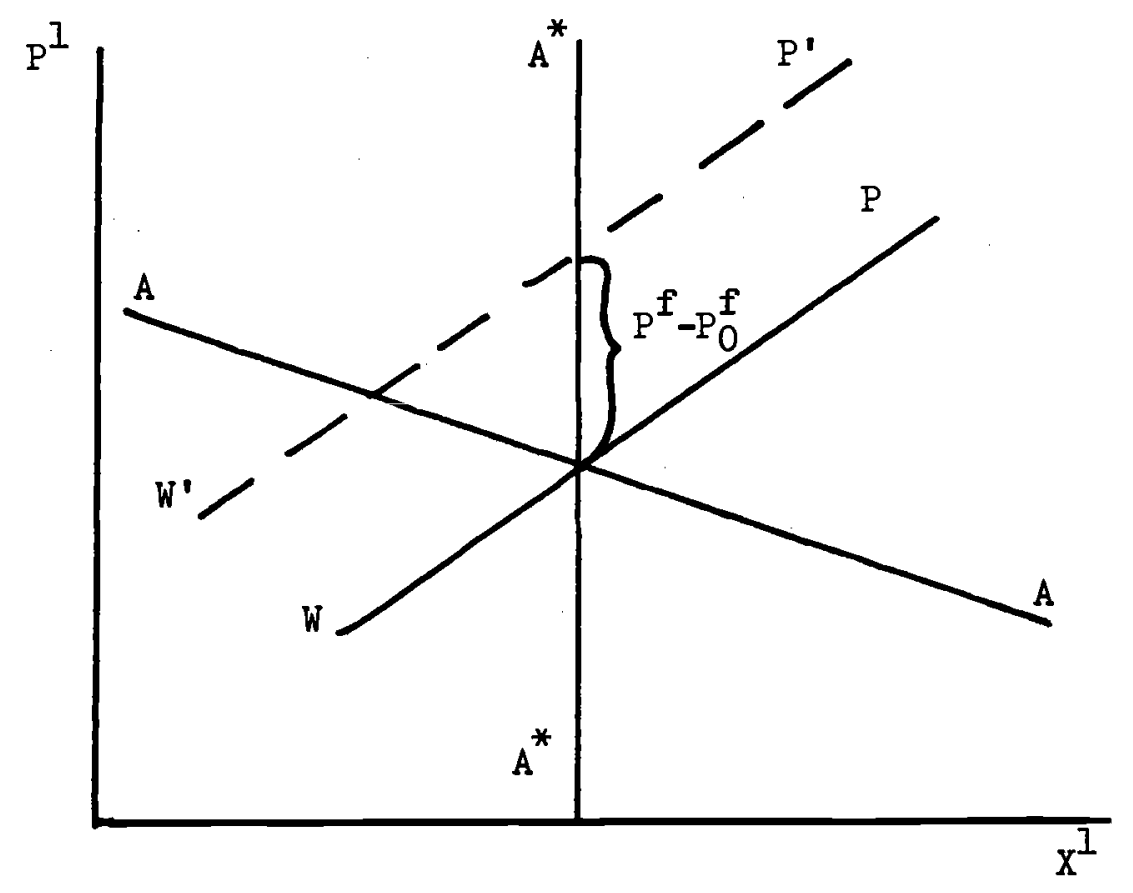

Figure 1. Impact of a Foreign Price Disturbance under Fixed $\left(A^{*} A^{*}\right)$ or Flexible (AA) Exchange Rates.

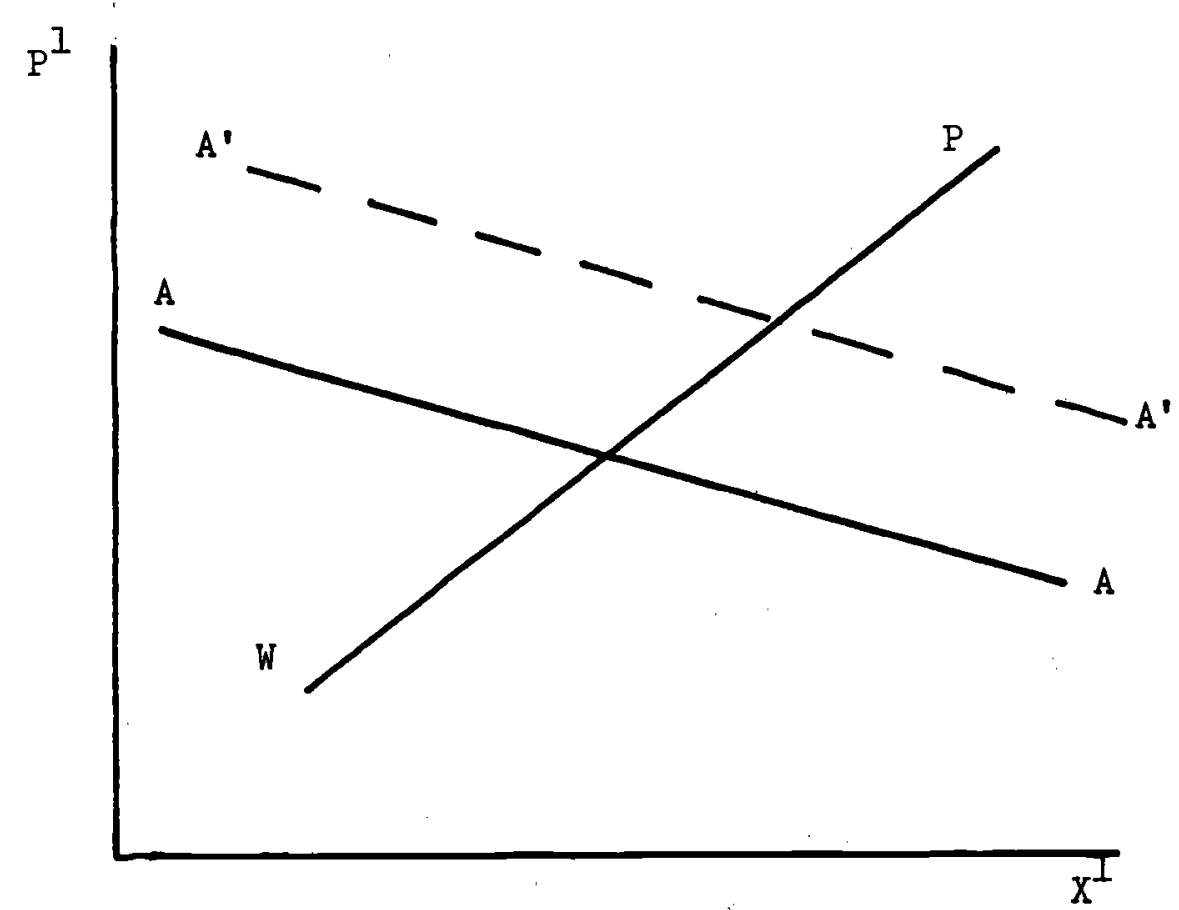

Figure 2. Impact of a Capital Account Disturbance with Fully Indexed Prices. 
AA represents those combinations of $\mathrm{P}^{\mathcal{l}}$ and $\mathrm{X}^{1}$ which keep the asset markets in equilibrium. A higher price level increases the transactions demand for money and the domestic interest rate. To restore equilibrium to the asset market, the exchange rate must fall (the domestic currency must appreciate).

\section{B. Behavior in an Exchange-Rate Union}

In an exchange-rate union between countries 1 and 2 , the monetary authorities intervene in the exchange market to keep fixed the franc price of the mark, $\mathrm{x}^{12}=\mathrm{x}^{1} / \mathrm{x}^{2}$. The franc and mark prices of the dollar then float together: $\left(\mathrm{X}^{1}-\mathrm{X}_{0}^{1}\right)=\left(\mathrm{X}^{2}-\mathrm{X}_{0}^{2}\right)$. Suppose that the foreign exchange intervention is carried out by the monetary authority of country 1 who buys (or sells) country 2's currency and sells (or buys) country l's currency to keep $\mathrm{X}^{12}$ fixed. (The results would be the same if country 2 carried out this intervention. $)^{11}$ The four asset equations described above would then determine $r^{1}, r^{2}, x^{1}=x^{2}$, and $M^{2 m}$, the last variable representing the holdings of country 2's currency by country I's monetary authority. The four equations can be solved for the dollar exchange rates as functions of nominal output in each country and the disturbances, $u^{\text {hi }}$ :

$$
\left(x^{i}-x_{0}^{i}\right)=B^{l}\left(P^{l} y^{l}-P_{0}^{l} y_{0}^{l}\right)+B^{2}\left(P^{2} y^{2}-P_{0}^{2} y_{0}^{2}\right)-\frac{\left(u^{h l}-u_{0}^{h l}\right)+\left(u^{h 2}-u_{0}^{h 2}\right)}{2\left(H_{x l}^{l}+H_{x 2}^{l}\right)}
$$

where $B^{I}=\frac{J^{11}+J^{2 l}}{2\left(\mathrm{H}_{\mathrm{x} I}^{1}+\mathrm{H}_{\mathrm{X} 2}^{I}\right)}<0, B^{2}=B^{I}$

1 Other more complex types of foreign exchange intervention involving the purchase or sale of securities might also be examined. Marston (1980) analyzes the effects of different types of intervention in a two-country model with stochastic disturbances.

${ }^{12} \mathrm{~B}^{1}$ must be negative because $\mathrm{J}^{11}+\mathrm{J}^{21}<0$ and $\mathrm{H}_{\mathrm{xl}}^{1}+\mathrm{H}_{\mathrm{x} 2}^{1}>0$ by the assumptions outlined above. 
This equation shows that an increase in prices or output in either country leads to a fall in both countries' dollar exchange rates.

Comparison of the coefficients in equations (2) and (3) provides some insight into the effects of a union. The coefficient of $\left(P^{i} y^{i}-P_{0}^{i} y_{0}^{i}\right)$ in equation (3), $\mathrm{B}^{\mathrm{i}}$, is the average of the coefficients of that same variable in the equations (2) for flexible exchange rates. ${ }^{13}$ By joining the union, countries $I$ and 2 find their dollar exchange rates sharing equally the effects of price disturbances in either country's market.

In the union a rise in $P^{2}$, for example, leads to an increase in country 2's interest rate and in the demand for country 2 's currency; as a result, there is an incipient rise in $\mathrm{X}^{12}$ and fall in $\mathrm{X}^{2}$. To prevent $\mathrm{X}^{12}$ from rising, the monetary authorities of country $I$ intervene in the exchange market, selling country 2's currency and buying its own currency. The excess demand for country 2 's currency is thereby reduced and the excess demand for country I's currency increased. The net result of the intervention is that $X^{I}$ and $X^{2}$ fall by the same amount, thereby cushioning the impact of country $2^{\prime}$ s price disturbance on country $2^{\prime}$ 's exchange rate.

As in the case of flexible exchange rates, the curve AA in Figure 1 can be used to describe the inverse relationship between the dollar exchange rate of either country, $x^{i}$, and the price of that country's goods. But it should be clear from the above discussion that the impact of any change in prices on that country's dollar exchange rate is moderated by intervention in the exchange market. Because exchange market intervention has the effect of dispersing the impact of a change in prices on either dollar exchange rate, $A A$ is steeper in the case of an exchange rate union $\left(A^{i i}<B^{i}<0\right)$. 13 That is, $\left(\mathrm{A}^{11}+\mathrm{A}^{21}\right) / 2=\mathrm{B}^{1}$ and $\left(\mathrm{A}^{12}+\mathrm{A}^{22}\right) / 2=\mathrm{B}^{2}$. 
C. The Effects of Capital Account Disturbances

With the alternative financial models specified, we can analyze the effects of economic disturbances on the financial markets of the two countries. In both exchange rate regimes, these disturbances will lead to changes in interest rates and exchange rates, which will in turn induce adjustments in prices and output. Of particular concern are the effects of the disturbances on the general price indices in each economy, since these price indices presumably reflect the purchasing power of local incomes (including wages, as will be seen below). For the two member countries, the general price indices are defined as follows:

$$
\begin{aligned}
& I^{1}=\left(P^{1}\right)^{a} 11\left(P^{2} X^{12}\right)^{a} 12\left(P^{3} X^{1}\right)^{a} 13 \\
& I^{2}=\left(P^{1} / X^{12}\right)^{a} 21\left(P^{2}\right)^{a} 22\left(P^{3} X^{2}\right)^{a} 23
\end{aligned}
$$

where $\sum_{j} a_{i j}=1$ for $i=1,2$.

Country I's price index, for example, is a function of the prices in francs of country 2's goods, U.S. goods, as well as its own goods. The analys is to follow will determine for each regime the effects of disturbances on the variances of these two price indices. In this section, adjustment in the financial markets alone will be considered, while in the next two sections the analysis will be extended to the labor and goods markets.

The economic disturbances which will be of central interest in the analysis are ones which directly affect one member country's currency vis-a-vis the dollar. The specific disturbances discussed in this section are random shifts between the securities of country 2 and the United States, 14 paper.

${ }^{14}$ Other types of disturbances are considered in later sections of the 
with $E\left(u^{h 2}\right)=E\left(u^{f 2}\right)=0, E\left[\left(u^{h 2}\right)^{2}\right]=\sigma_{h 2}^{2}, E\left[\left(u^{f 2}\right)^{2}\right]=\sigma_{f 2}^{2}$, and $E\left(u^{h 2} u^{f 2}\right)=$ $-\sigma_{h 2} \sigma_{f 2}$. These capital account disturbances will induce changes in the mark price of the dollar. But, in addition, under flexible exchange rates such disturbances will also change the cross exchange rate between the franc and the mark and the franc price of the dollar.

By using equations (2) and (3), we can obtain expressions for the changes in the exchange rates associated with a shift out of country 2 's securities into the dollar security $\left(u^{h 2}-u_{0}^{h 2}<0\right)$. Under flexible exchange rates, these changes are given by:

$$
\begin{aligned}
& \left(x^{1}-x_{0}^{1}\right)=\frac{H_{x 2}^{1}}{A}\left(u^{h 2}-u_{0}^{h 2}\right)>0, \\
& \left(x^{2}-x_{0}^{2}\right)=\frac{-H^{1}}{A}\left(u^{h 2}-u_{0}^{h 2}\right)>0, \\
& \left(x^{12}-x_{0}^{12}\right)=\frac{\left(H_{x 1}^{1}+H_{x 2}^{1}\right)}{A}\left(u^{h 2}-u_{0}^{h 2}\right)<0 .
\end{aligned}
$$

This shift out of mark securities causes both dollar rates to rise, but the mark price of the dollar rises more than the franc price, implying that the cross exchange rate, the franc price of the mark, must fall. Notice that the changes in $x^{1}$ and $x^{12}$ are dependent upon the two excess demand coefficients discussed earlier. When country l's financial market is highly integrated only with the dollar market (so that $\left(\mathrm{H}_{\mathrm{x} l}^{1}+\mathrm{H}_{\mathrm{x} 2}^{1}\right.$ ) is relatively large), $\mathrm{x}^{12}$ must adjust more than $x^{1}$. When the member countries are highly integrated only with one another $\left(H_{\mathrm{x} 2}^{\perp}\right.$ is relatively large in absolute value), $\mathrm{X}^{\mathrm{I}}$ must adjust more than $\mathrm{x}^{12}$.

In a union, in contrast, the two dollar exchange rates rise in tandem since the cross rate is fixed: 


$$
\left(x^{i}-x_{0}^{i}\right)=\frac{\left(H_{x 2}^{I}-H_{x I}^{I}\right)}{2 A}\left(u^{h 2}-u_{0}^{h 2}\right)>0
$$

It is readily apparent from expressions (5) and (6) that formation of the union reduces the impact of the disturbance on the mark price of the dollar. ${ }^{15}$ That is because foreign exchange intervention associated with the union helps to disperse the effects of the disturbance to country 1's markets. ${ }^{16}$ For the same reason, the union increases the impact of the disturbance on the franc price of the dollar. In fact, the change in either dollar exchange rate in the union is just the average of the changes in the dollar rates in expression (5).

To determine the effects of the capital account disturbance on the general price levels in each country, the expressions for $I^{I}$ and $I^{2}$ in (4) are first linearized around their equilibrium values $\left(I_{0}^{1}=I_{0}^{2}=1\right.$ ), where all prices and exchange rates are set initially at unity. Using the equations in (5), $\left(I^{1}-I_{0}^{1}\right)$ and $\left(I^{2}-I_{0}^{2}\right)$ can be expressed as functions of $\left(u^{h 2}-u_{0}^{h 2}\right)$. The variances of $I^{l}$ and $I^{2}$ can then be written as follows for the case of flexible exchange rates:

$$
\begin{aligned}
& \sigma_{I 1}^{2}=\left[\frac{a_{12}\left(H_{x l}^{I}+H_{x 2}^{I}\right)+a_{13} H_{x 2}^{I}}{A}\right]^{2} \sigma_{h 2}^{2} \quad \frac{\text { Flexible Exchange }}{\text { Rates }} \\
& \sigma_{I 2}^{2}=\left[\frac{-a_{21}\left(H_{x 1}^{I}+H_{x 2}^{I}\right)-a_{23} H_{x I}^{I}}{A}\right]^{2} \sigma_{h 2}^{2}
\end{aligned}
$$

15 As noted above, $0<-\mathrm{H}_{\mathrm{x} 2}^{\mathrm{I}}<\mathrm{H}_{\mathrm{x} 1}^{\mathrm{I}}$. Thus, in expressions (5) and (6), $0>\mathrm{H}_{\mathrm{x} 2}^{\mathrm{I}}>\frac{\left(\mathrm{H}_{\mathrm{x} 2}^{1}-\mathrm{H}_{\mathrm{xl}}^{1}\right)}{2}>-\mathrm{H}_{\mathrm{xI}}^{1}$.

${ }^{16}$ If both countries experience capital account disturbances, intervention has the more limited role of evening out any fluctuations in the cross rate. (See Section III.) 
The changes in the general price levels depend partly upon the consumption weights, $a_{i j}$. But also important are the excess demand factors determining (for the case of a shift out of mark securities) how much the mark and franc depreciate relative to the dollar and how much the franc appreciates relative to the mark. (See (5) above.)

Consider first the variance of country 2 's price level, $\sigma_{\text {I2. }}^{2}$ If there is a shift from the bonds of country 2 to U.S. bonds, the mark depreciates relative to both the U.S. dollar and the franc. This mark depreciation raises the general price level of country 2 by raising both the mark price of U.S. goods (with weight $\mathrm{a}_{23}$ ) and the mark price of country $I^{\prime}$ 's goods (with weight $\left.a_{21}\right)$.

The effects of capital account disturbances on country l's price level are not as clear-cut. In response to a shift out of mark bonds, the franc appreciates relative to the mark and depreciates relative to the dollar. The franc price of country 2 's goods falls and the franc price of U.S. goods rises, so the general price level can rise or fall in response to this disturbance. The net effect on the price level depends upon the condition:

$$
I^{1} \gtrless 0 \text { as } \frac{a_{12}}{a_{13}} \leqq \frac{-H_{x 2}^{1}}{\left(H_{x 1}^{1}+H_{x 2}^{1}\right)} \text {. }
$$

The two sets of factors involved are the share of country 2 's goods and U.S. goods in country I's consumption $\left(a_{12}\right.$ and $\left.a_{13}\right)$, and the response of the excess demand for country $I^{\prime}$ 's bonds to changes in exchange rates. To examine the influence of the exchange rates, assume that the consumption shares are equal $\left(a_{12}=a_{13}\right)$. If the demand for country l's bonds is highly sensitive only to the dollar exchange rate (in which case $\left(\mathrm{H}_{\mathrm{x} 1}^{I}+\mathrm{H}_{\mathrm{x} 2}^{I}\right.$ ) is large relative to 
$\left(-\mathrm{H}_{\mathrm{x} 2}^{\perp}\right)$, then the franc will vary mainly against the mark rather than the dollar. This would be the case if country l's financial market is more highly integrated with the dollar market than with country 2's market. The general. price level of country 1 then will fall in response to this disturbance. The general price level will rise in the opposite case where the member countries' financial markets are highly integrated with one another but not with the dollar market. The degree of financial integration between countries 1 and 2, therefore, is a crucial element here.

There is an interesting intermediate case where the general price level is stable in the face of this disturbance. If the excess demand for $\mathrm{H}^{1}$ is equally sensitive to both exchange rates, then increases in the franc price of U.S. goods will offset declines in the franc price of country 2's goods. Country l's general price level will be effectively insulated from this disturbance unless $a_{12}$ is markedly different from $a_{13}$.

Now consider changes in the general price level in an exchange-rate union where $\left(x^{1}-x_{0}^{1}\right)=\left(x^{2}-x_{0}^{2}\right)$ and where $\left(x^{12}-x_{0}^{12}\right)=0$. The variances of the price levels in the two countries are given by:

$$
\begin{array}{ll}
\sigma_{I 1}^{2}=\left[\frac{a_{13}\left(H_{x 2}^{I}-H_{x I}^{I}\right)}{2 A}\right]_{h 2}^{2} \sigma_{h}^{2} & \frac{\text { Exchange-Rate }}{\underline{\text { Union }}} \\
\sigma_{I 2}^{2}=\left[\frac{a_{23}\left(H_{x 2}^{I}-H_{x l}^{I}\right)}{2 A}\right]_{h 2}^{2} \sigma_{h 2}^{2} &
\end{array}
$$

\section{Exchange-Rate}

Both countries experience changes in their general price level only to the extent to which their dollar exchange rates change. And the changes in $x^{1}$ and $\mathrm{x}^{2}$ are weighted only by the share of U.S. goods in their trade, $\mathrm{a}_{13}$ and $a_{23}$, respectively. 
To compare experience in the two exchange-rate regimes, consider first the case of country 2. Since in a union the cross exchange rate between the mark and the franc is fixed, that source of variation in country 2 's general price index (with weight $a_{21}$ ) is eliminated. In addition, the response of its dollar exchange rate to any disturbance is reduced because of the effect of foreign exchange intervention in dispersing excess demand from one country's market to another. Thus, the variance of $I^{2}$ arising from changes in the mark price of U.S. goods is also reduced. Country 2 clearly gains by joining the union.

Country 1, in contrast, may gain or lose. Introduction of the union will raise the variance of country l's price level if the financial markets of the member countries are highly integrated, whether or not these markets are highly integrated with the dollar market. Consider first the case where the integration with the dollar market is relatively low. In that case, country I's price level will vary mainly because $\mathrm{X}^{l}$ varies in response to this disturbance. But it was shown previously that introduction of the union increases the movement of $X^{l}$, so the variance of $I^{l}$ must be greater in the union. Secondly, consider the case where the three markets are equally well integrated. Then, under fully flexible rates, $x^{12}$ will move in the opposite direction from $x^{l}$, thus helping to insulate country I's price level from the effects of the disturbance. ${ }^{17}$ By joining the union, country 1 loses the benefit of this insulation.

Only in the case where the member countries' financial markets are

17 Note that country 1 is insulated from changes in the general price level but not from changes in relative prices. Changes in relative prices between countries 1 and 2 (or between the U.S. and country 1 ) may be an independent source of concern (for example, because they affect resource allocation). 
highly integrated with the dollar market alone can a union actually reduce the variance of $I^{l}$. In that case, the capital account disturbance will have its greatest impact on the cross exchange rate between the franc and the mark. By joining the union, country 1 will be able to fix this cross rate and thereby substitute variability in the domestic price of U.S. goods for variability in the price of country $2^{\prime} \mathrm{s}$ goods. The more important is trade between the member countries as opposed to trade with the United States, the more will the variance of $I^{1}$ be reduced through this effect. ${ }^{18}$ The conclusion of this analysis is that an exchange-rate union benefits one member country but not necessarily the other. The country which is susceptible to capital account disturbances must gain as a result of the union, partly because a union stabilizes the important cross exchange rate between member currencies, but also because the union helps to disperse the disturbance into the financial market of the other country. The other country may gain if trade within the union is especially important, but only if financial markets in the absence of a union fail to moderate movements in the cross exchange rate. Otherwise, union will actually increase the variance of its price level.

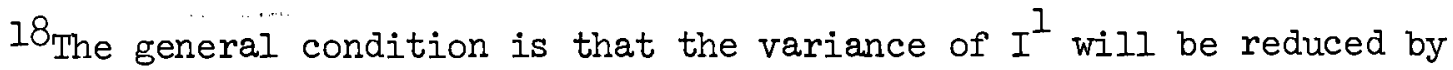
joining the union only if

$$
a_{13}\left(H_{x 1}^{I}-H_{x 2}^{I}\right) / 2<a_{12}\left(H_{x 1}^{I}+H_{x 2}^{1}\right)+a_{13} H_{x 2}^{1} \text {. }
$$

Note that the first term on the right side of the inequality is positive, while the second is negative. For the variance of $I^{l}$ to be reduced, the share of trade with country 2 must be relatively important, but so also must the relative impact of the disturbance on the cross exchange rate in the absence of a union, as reflected in $\left(\mathrm{H}_{\mathrm{x} 1}^{1}+\mathrm{H}_{\mathrm{x} 2}^{\perp}\right)$. 
The next sections of the paper will extend the analysis to the markets for labor and goods. Section II will introduce equations to explain wages, domestic prices, and output, and will investigate the response of this extended model to several types of disturbances. Section III will then return to the comparison of exchange rate unions with flexible exchange rates.

\section{Prices and Wages Under Flexible Exchange Rates}

In this section, a simple model of the goods and labor markets will be introduced. The specification chosen is meant to emphasize the importance of three factors:

1. wage indexation behavior by which the labor force protects itself from the effects of price changes, including those originating in exchange rate changes;

2. direct and indirect linkages between prices in different countries; and

3. varying degrees of substitutibility between foreign and domestic goods .

The model is meant to be general enough to encompass a variety of different forms of behavior in the labor and goods markets, but specific enough in functional form to simplify the analysis.

\section{A. Outline of the Model}

Prices exhibit markedly different behavior under the alternative assumptions of fixed money wages and fixed real wages. The specification of wage behavior in this paper is chosen so as to encompass these two extreme forms of behavior, while allowing for the intermediate possibility of

limited adjustment of nominal wages to prices. If $W^{\perp}$ is the money wage of 
country $I$ and $I^{I}$ the price index, wage behavior is described by equation (9):

$$
W^{I}=\bar{b}_{1}\left(I^{1}\right)^{b}
$$

The exponent, $b_{1}$, is called the wage indexation parameter, where

$$
0 \leq b_{1} \leq 1
$$

This parameter may reflect wage-price linkages embodied in formal indexation agreements, or may simply reflect the responses of market-determined wages to price changes. The general price index which is used in determining money wages, defined earlier in (4), includes foreign as well as domestic prices. The price of domestic goods is explained as a function of wages and the price of foreign goods:

$$
\mathrm{P}^{1}=\overline{\mathrm{C}}^{1}\left(\mathrm{w}^{1}\right)^{c_{11}}\left(\mathrm{P}^{2} \mathrm{X}^{12}\right)^{c_{12}}\left(\mathrm{P}^{3} \mathrm{X}^{1}\right)^{c_{13}}\left(\mathrm{y}^{1} / \overline{\mathrm{y}}^{1}\right)^{c_{14}}
$$

Equation (10) may be interpreted as a simple markup equation which relates $\mathrm{P}^{1}$ to wages and the cost of imported materials; in that case, $\overline{\mathrm{C}}^{1}\left(\mathrm{y}^{1} / \overline{\mathrm{y}}^{1}\right)^{\mathrm{c}}{ }^{14}$ is a markup term which varies with output relative to capacity output $\left(\bar{y}^{l}\right)$. The coefficients $c_{11}, c_{12}, c_{13}$ would satisfy the inequality $c_{11}+c_{12}+c_{13} \leq 1$. Alternatively, the foreign prices may capture the influence of foreign competition on the domestic price markup. ${ }^{20}$ Finally, if the domestic industry is perfectly competitive (with a Cobb-Douglas technology, for example), then the markup will again vary with output and the coefficients of wages and

19For studies of wage indexation behavior, see Fischer (1977), Gray (1976), Modigliani and Padoa-Schioppa (1978), and Sachs (1979); the latter two studies deal with open economies.

20 For a similar formulation, see Modigliani and Padoa-Schioppa (1978). 
foreign prices will satisfy the equality $c_{11}+c_{12}+c_{13}=1$ (so that equation (10) is homogeneous of degree one in wages and prices). Whichever interpretation is given to equation (10), the specification is broad enough to allow for a direct influence of foreign on domestic prices, or to allow foreign prices to affect domestic prices only indirectly through wage indexation (in which case, $c_{1 I}=I$ in the homogeneous case).

The demand for the output of the domestic industry is expressed as a function of foreign prices relative to domestic prices as well as an exogenous element, $\vec{G}^{1}$, representing government spending, foreign income, as well as other variables: ${ }^{21}$

$$
\mathrm{y}^{1}=\left[\left(\mathrm{P}^{2} \mathrm{x}^{12}\right) / \mathrm{P}^{1}\right]^{\mathrm{g}}\left[\left(\mathrm{P}^{3} \mathrm{x}^{1}\right) / \mathrm{P}^{12}\right]^{\mathrm{g}} \overline{\mathrm{G}}^{1}
$$

with $g_{12}, g_{13} \geq 0$. The coefficients $g_{12}$ and $g_{13}$ reflect the degree of substitutibility between domestic and foreign goods; if foreign and domestic goods are perfect substitutes, these coefficients approach a limiting value of infinity.

The equations describing behavior in the goods and labor markets together provide a second relationship between the exchange rate and domestic price reflecting the impact of foreign prices on the domestic wage and the price of domestic output. To derive this relationship, equations (9), (4), (10) and (11) are linearized around the equilibrium values of prices $\left(P_{0}^{1}, P_{0}^{2}, P_{0}^{3}\right)$, wages $\left(W_{0}^{1}\right)$, and the exchange rates $\left(X_{0}^{1}, X_{0}^{2}, X_{0}^{12}\right)$, all of which are set equal to unity, as well as domestic output $\left(y_{0}^{1}\right)$. After solving this system of equations for the domestic price as a function of the exchange

${ }^{2}$ Similar demand functions are found in Dornbusch (1976) and Sachs (1979). Note that equation (1I) for simplicity ignores the impact of interest rates on aggregate demand. 
rates and foreign prices, the result is the following equation:

$$
\left(\mathrm{P}^{1}-\mathrm{P}_{0}^{1}\right)=\mathrm{E}^{12}\left[\left(\mathrm{P}^{2}-\mathrm{P}_{0}^{2}\right)+\left(\mathrm{x}^{1}-\mathrm{x}_{0}^{1}\right)-\left(\mathrm{x}^{2}-\mathrm{x}_{0}^{2}\right)\right]+\mathrm{E}^{13}\left[\left(\mathrm{P}^{3}-\mathrm{P}_{0}^{3}\right)+\left(\mathrm{x}^{1}-\mathrm{x}_{0}^{1}\right)\right]
$$

where $\mathrm{E}^{12}=\left(c_{12}+c_{11} b_{1} a_{12}+c_{14} g_{12}\right) /\left[1-c_{11} b_{1} a_{11}+c_{14}\left(g_{12}+g_{13}\right)\right]$,

$$
E^{13}=\left(c_{13}+c_{11} b_{1} a_{13}+c_{14} g_{13}\right) /\left[1-c_{11} b_{1} a_{11}+c_{14}\left(g_{12}+g_{13}\right)\right] \text {. }
$$

The coefficients $\mathrm{E}^{12}$ and $\mathrm{E}^{13}$ are crucial parameters in the model since they incorporate both the direct and indirect influences of foreign prices and exchange rates on the domestic price.

Country $I$ is said to be fully indexed if these coefficients sum to unity: $E^{12}+E^{13}=1$; that is, if a rise in the domestic currency prices of both foreign goods leads to an equal increase in the price of the domestic good. From the expressions for $\mathrm{E}^{12}$ and $\mathrm{E}^{13}$, it is evident that a fully indexed domestic price can arise in two circumstances: In the familiar case where foreign and domestic goods are perfect substitutes $\left(g_{12}, g_{13}=\infty\right)$, the sum of these coefficients approaches a limiting value of one; since consumers treat the domestic and foreign goods as indistinguishable, the law of one price must hold and changes in the domestic currency prices of the foreign goods induce equal changes in the price of the domestic good. Alternatively, if the wage indexation parameter, $b_{1}$, is equal to one, so that increases in foreign (or domestic prices) are fully reflected in wage costs, then the domestic price will be fully indexed regardless of the degree of substitutibility between domestic and foreign goods. ${ }^{22}$ In the analysis

\footnotetext{
${ }^{22}$ In addition, the price equation must be homogeneous of degree one $\left(c_{11}+c_{12}+c_{13}=1\right)$, so that increases in wage costs and the costs of foreign goods are fully passed on to the domestic price.
} 
to follow, only the latter case of full wage indexation will be referred to, but the reader may wish to keep in mind the alternative interpretation in terms of perfect substitutibility between goods. 23

\section{B. Interaction Between Prices and Exchange Rates}

In order to investigate the interaction between the wage-price sector and the asset sector described earlier, consider a simplified version of the above equations where there is only one foreign country with a price of $\mathrm{P}^{f}$ and a single exchange rate of $x^{l}$. Equation (12) can then be rewritten as follows: 24

$$
\left(P^{I}-P_{O}^{l}\right)=E^{I}\left[\left(P^{f}-P_{O}^{f}\right)+\left(X^{1}-X_{0}^{1}\right)\right]
$$

In Figure 1, the curve WP reflects the wage-price behavior implicit in ( $\left.12^{\prime}\right)$. WP has a slope equal to one when the domestic price is fully indexed, and a slope of less than one otherwise. Similarly, with one foreign country the asset market equation for country $I$ (equation (2)) can be rewritten in simplified form: 25

$$
\left(\mathrm{X}^{1}-\mathrm{X}_{0}^{1}\right)=\mathrm{A}^{1}\left(\mathrm{P}^{1} \mathrm{y}^{1}-\mathrm{P}_{0}^{1} \mathrm{y}_{0}^{1}\right)-\left(\mathrm{u}^{\mathrm{hl}}-\mathrm{u}_{0}^{\mathrm{hl}}\right) / \mathrm{H}_{\mathrm{x}}^{1}
$$

As before, AA reflects the inverse relationship between prices and the exchange rate based on the transactions demand for money.

23 The emphasis on wage indexation reflects recent interest in how the transmission of disturbances is affected by varying degrees of indexation in different countries. See, for example, Branson and Rotemberg (1979) and Sachs (1979).

$24 \mathrm{E}^{1}$ is the counterpart of $\mathrm{E}^{1 j}$ for the case of a single foreign country.

$25 \mathrm{~A}^{1}$ is the single country counterpart of $\mathrm{A}^{i \mathrm{i}}$, while $1 / \mathrm{H}_{\mathrm{X}}^{1}$ is the counterpart of $\mathrm{H}_{\mathrm{Xj}}^{j} / \mathrm{A}$. Note that $\mathrm{A}^{\mathrm{I}}<0$ and $\mathrm{H}_{\mathrm{X}}^{\mathrm{I}}>0$. 
Figure $I$ shows that the domestic price and exchange rate are simultaneously determined by portfolio behavior and wage and price behavior (where output for the present is assumed to be exogenously fixed at $\mathrm{y}^{1}=\mathrm{y}_{0}^{1}$ ). To examine this relationship in more detail, equations (2') and (12') are solved to obtain reduced form expressions for $\mathrm{X}^{l}$ and $\mathrm{P}^{l}$ (expressed as deviations from their equilibrium values):

$$
\begin{aligned}
& \left(X^{I}-X_{0}^{l}\right)=\frac{A^{I} y_{0}^{I} E^{l}\left(P^{f}-P_{0}^{f}\right)-\left(u^{h l}-u_{0}^{h l}\right) / H_{X}^{I}}{\left(I-E^{I} A^{I} y_{0}^{I}\right)} \\
& \left(P^{I}-P_{0}^{I}\right)=\frac{E^{I}\left(P^{f}-P_{0}^{f}\right)-E^{I}\left(u^{h l}-u_{0}^{h l}\right) / H_{x}^{l}}{\left(1-E^{l} A^{l} y_{0}^{l}\right)}
\end{aligned}
$$

The change in the general price index for country $1, I^{l}$, is also written in simple terms as follows:

$$
\left(I^{I}-I_{0}^{I}\right)=a_{I I}\left(P^{I}-P_{0}^{I}\right)+\left(I-a_{I I}\right)\left[\left(P^{f}-P_{0}^{f}\right)+\left(X^{I}-x_{0}^{I}\right)\right]
$$

Using this system of equations, we will analyze how prices and exchange rates respond to two sets of disturbances: a change in the foreign price and a portfolio shift between domestic and foreign bonds (capital account disturbance).

\section{Foreign price disturbance}

To emphasize the importance of wage indexation in determining the response of the system to foreign price changes, we will first consider the case of fixed exchange rates where the asset curve ( $A^{*} A^{*}$ in Figure 1 ) is vertical. 26 A rise in foreign prices, $\left(P^{f}-P_{O}^{f}\right)>0,{ }^{27}$ shifts the WP curve up ${ }^{26}$ Equation (14) is replaced by $\left(12^{\prime}\right)$, where $\left(x^{1}-x_{0}^{1}\right)=0$.

27 Foreign interest rates are assumed to be constant when foreign prices rise. 
by less than the change in foreign prices if wages are not fully indexed. In contrast, with full indexation (the case illustrated), the foreign price disturbance induces an equal increase in domestic prices. In both cases, the monetary sector accommodates the increase in prices through an inflow of foreign exchange reserves and an increase in the domestic interest rate. With $\mathrm{P}^{I}$ and $\mathrm{P}^{f}$ increasing by the same amount, the general price index, $\mathrm{I}^{\mathrm{l}}$, must clearly increase by that amount as well.

With flexible exchange rates, the economy achieves some insulation from foreign price disturbances. An increase in the foreign price level induces an increase in domestic wages and prices, but the money supply can no longer adjust to accommodate the increase in prices. As a result, the domestic interest rate rises and the exchange rate falls; the domestic currency price of foreign goods rises less than the foreign currency price. Therefore, the price of domestic goods rises less than under fixed exchange rates.

Consider the case of full indexation illustrated in Figure 1. A rise in the foreign price level leads to a fall in the exchange rate and rise in the domestic price as shown. How much $\mathrm{P}^{l}$ rises and $\mathrm{X}^{1}$ falls depends upon the slope of $\mathrm{AA}$ (the inverse of $\mathrm{A}^{1} \mathrm{Y}_{0}^{1}$ ) and therefore upon behavior in the asset market. $^{28}$. But as long as the economy is fully indexed, the price of

${ }^{28}$ In the case where domestic and foreign bonds are perfect substitutes, so that the demand for each bond is infinitely sensitive to changes in either interest rate, the domestic economy can be fully insulated from foreign price increases. Consider the coefficient of the domestic price, $\mathrm{A}^{1}$, in the asset market equation ( $\left.2^{\prime}\right)$; when there is a single foreign country, $A^{1}$ can be expressed in terms of the underlying asset demand functions as follows:

$$
A^{1}=\frac{h_{1}^{11} m_{y}^{1}-m_{1}^{1} h_{y}^{11} \ldots}{m_{1}^{1} F_{0}^{1}\left(h^{11}(\cdot)-h_{\left.\frac{\mathrm{y}}{11} \mathrm{P}_{0}^{1} \mathrm{y}_{0}^{1} / v_{0}^{1}\right)}\right.},
$$

where $h_{1}^{11}, h_{\mathrm{y}}^{11}$ are the derivatives of the domestic bond function with respect to the domestic interest rate and the level of transactions, respectively, 
domestic output $\left(\mathrm{P}^{1}\right)$, the domestic currency price of foreign output $\left(\mathrm{X}^{1} \mathrm{P}^{\mathrm{f}}\right)$, and therefore the general price index, all rise by the same amount: $\left(P^{f}-P_{0}^{f}\right) /\left(I-A^{l} y_{0}^{l}\right)$; since $A^{I}<0$, this change in domestic prices must be less than the initial change in foreign prices. The variance of the general price level in country $I$ under full indexation is equal to $\sigma_{\text {Il }}^{2}=\sigma_{f}^{2} /$ $\left(1-A^{1} y_{0}^{1}\right)^{2}$, where $\sigma_{f}^{?}$ is the variance of the foreign price level.

\section{Capital account disturbance}

In Section I of this paper, a disturbance involving country 2's capital account was discussed in a model where prices were exogenous. Now that a wage-price sector has been added, a similar disturbance will be analyzed. The disturbance takes the form of a shift out of country l's bond into the foreign (dollar) bond $\left(U^{h l}-U_{0}^{h l}\right)<0$ in equation $\left(2^{\prime}\right)$, which shifts the AA curve in Figure 2 to the right. As in the analysis of the asset market alone, this shift out of the domestic bond leads to a rise in $X^{1}$ (depreciation of the home currency). But now that depreciatinn raises the domestic price as well, if wages respond to changes in the general price level or if foreign prices directly influence domestic prices.

If domestic prices are less than fully indexed $\left(\mathrm{E}^{1}<1\right)$, then the capital account disturbance will lead to a change in the exchange rate greater than the change in domestic prices (the slope of WP is less than one). Let the terms of trade be defined as the ratio of the price of

(Footnote 28 continued)

and where the money demand derivatives are defined analogously. If domestic and foreign bonds are perfect substitutes, so that $h^{1}{ }^{1}=\infty$, then $A^{1}=-\infty$. The curve AA in Figure 1 becomes flat, and changes in foreign prices therefore lead to offsetting changes in the exchange rate, while the domestic price remains constant. 
domestic goods to the domestic currency price of foreign goods: $T=P^{I} /\left(X^{7} P^{f}\right)$. As a result of the capital account disturbance, this ratio will fall, thereby making domestic goods more attractive. By equation (11), domestic demand and output will rise in response to this change in the terms of trade.

If domestic prices are fully indexed (the case shown in Figure 2), the results are quite different. $P^{l}$ and $X^{I}$ both rise as before, but they increase by the same amount:

$$
\left(\mathrm{P}^{I}-\mathrm{P}_{0}^{l}\right)=\left(\mathrm{X}^{I}-\mathrm{X}_{0}^{I}\right)=-\left(\mathrm{u}^{\mathrm{hl}}-\mathrm{u}_{0}^{\mathrm{hl}}\right) / \mathrm{H}_{\mathrm{x}}^{I}\left(I-\mathrm{A}^{I} \mathrm{y}_{0}^{I}\right)
$$

Therefore, there is no change in the terms of trade, and the general price level rises as much as $\mathrm{P}^{1}$ or $\mathrm{X}^{1}{ }^{29}$

In the analysis to follow in the next section, these same disturbances will be analyzed within the context of an exchange-rate union. For this purpose, the domestic price equation for country 2 is set out below:

$$
\begin{aligned}
\left(\mathrm{P}^{2}-\mathrm{P}_{0}^{2}\right)= & \mathrm{E}^{21}\left[\left(\mathrm{P}^{1}-\mathrm{P}_{0}^{1}\right)+\left(\mathrm{X}^{2}-\mathrm{X}_{0}^{2}\right)-\left(\mathrm{X}^{1}-\mathrm{X}_{0}^{1}\right)\right]+\mathrm{E}^{23}\left[\left(\mathrm{P}^{3}-\mathrm{P}_{0}^{3}\right)\right. \\
& \left.+\left(\mathrm{X}^{2}-\mathrm{X}_{0}^{2}\right)\right] .
\end{aligned}
$$

The coefficients in equation (17) are entirely analogous to those defined earlier in equation (12). As in the case of $\mathrm{P}^{1}$, full indexation of country $2^{\prime} \mathrm{s}$ price, $\mathrm{P}^{2}$, occurs when the two coefficients (in this case, $\mathrm{E}^{21}+E^{23}$ ) sum to unity.

${ }^{29}$ The variance of the general price level is therefore:

$$
\sigma_{I l}^{2}=\sigma_{h l}^{2} /\left[_{\mathrm{X}}^{1}\left(I-\mathrm{A}^{1} \mathrm{y}_{0}^{1}\right)\right]^{2} .
$$


III. Prices and Exchange Rates in an Exchange-Rate Union

In Section I, the financial behavior of two potential member countries of an exchange-rate union was examined in detail. That section showed how the member countries were affected by a capital account disturbance originating in the financial market of one member. Formation of the union unambiguously benefitted the member country suffering the disturbance, but increased the variance of the general price level in the other country if the financial markets of the two countries were sufficiently well integrated in the absence of a union.

One weakness of the earlier analysis lay in its assumption of exogenous wages and prices for the output of each country. In this section, the earlier analysis will be modified to allow for the type of wage and price adjustment outlined in section II. To emphasize how much difference price adjustment can make, prices will be assumed to be fully indexed in the sense discussed above. 30 Thus, the analyses in sections I and III may be considered polar cases representing the extremes of no adjustment and full indexation of domestic prices.

Besides extending the earlier analysis of a capital account disturbance in one market, this section will also consider the effects of two other types of disturbances: changes in the price of U.S. goods and capital account disturbances affecting the financial markets of both member countries.

${ }^{30}$ Since, in these circumstances the terms of trade are constant, changes in output as given by (11) will be ignored. 


\section{A. Foreign Price Disturbances}

There are some disturbances for which an exchange-rate union is likely to make little difference. One example is a change in U.S. prices, which has its primary impact on both dollar exchange rates, $\mathrm{x}^{1}$ and $\mathrm{x}^{2}$, rather than on the cross rate between the currencies of the members, $x^{12}$.

Under flexible exchange rates, fluctuations in the U.S. price, $\mathrm{P}^{3}$, induce changes in the prices $\left(\mathrm{P}^{1}, \mathrm{P}^{2}\right)$ and dollar exchange rates $\left(\mathrm{X}^{1}, \mathrm{x}^{2}\right)$ of both member countries. Higher U.S. prices, for example, increase wages and prices in countries 1 and 2. Interest rates rise in both countries, so $\mathrm{X}^{1}$ and $\mathrm{X}^{2}$ fall (the franc and mark appreciate relative to the dollar). How much each dollar exchange rate responds to the change in $\mathrm{P}^{3}$ depends upon the parameters in the asset equations (2), $A^{i l}$ and $A^{i 2}$, reflecting the sensitivity of asset demands to prices, exchange rates, and interest rates. ${ }^{31}$ Fluctuations in the general price levels of each country similarly depend upon the asset parameters. If $\sigma \frac{2}{p 3}$ is the variance of the U.S. price, then the variances of $I^{l}$ and $I^{2}$ under flexible exchange rates are given by:

$$
\begin{aligned}
& \sigma_{I 1}^{2}=\sigma_{\mathrm{p} 3}^{2} /\left[\mathrm{I}-\left(\mathrm{A}^{1 I_{+}}+\mathrm{A}^{12}\right) \mathrm{y}_{0}\right]^{2} \\
& \sigma_{\mathrm{I} 2}^{2}=\sigma_{\mathrm{p} 3}^{2} /\left[\mathrm{I}-\left(\mathrm{A}^{22}+\mathrm{A}^{21}\right) \mathrm{y}_{0}^{2}\right]^{2}
\end{aligned}
$$

In an exchange-rate union, the variances of the general price levels are:

$$
\sigma_{I I}^{2}=\sigma_{I 2}^{2}=\sigma_{\mathrm{p} 3}^{2} /\left[1-\left(B^{1}+B^{2}\right) y_{a}^{1}\right]^{2}
$$

${ }^{3} l_{\text {Recall }}$ that in the case of a single foreign country, the change in $\mathrm{X}^{1}$ depended upon the slope of the $\mathrm{AA}$ schedule reflecting the asset market parameter, $\mathrm{A}^{\mathrm{l}}$. (See Section II.) 
Since we have assumed that financial behavior in the two member countries is identical, all of these variances must be equal. 32 In the absence of a union, the dollar exchange rates and prices of countries 1 and 2 respond alike to changes in U.S. prices. So formation of the union can make no contribution to price stability.

If, instead, there were asymmetries between the member countries dependent on relative size or other factors, the union could play a limited role in the case of an external disturbance of this type. But that role would be limited to dispersing any excess demand pressure on the cross exchange rate arising from differences in the responses of $x^{1}$ and $x^{2}$ to the disturbance.

\section{B. Capital Account Disturbance Involving Country 2's Bonds $^{\prime}$}

In contrast with the foreign price disturbance, the capital account disturbance analyzed in Section I has asymmetrical effects on the two member countries in the absence of a union. As in the earlier discussion, this disturbance takes the form of random shifts between the bonds of country 2 and U.S. bonds.

The effects of this disturbance on the price levels in countries 1 and 2 can best be analyzed by first considering a special case. Suppose that the financial markets of the two countries are highly integrated only with the U.S. market. In that case, as shown in Section I, the capital account disturbance in country 2 's market will lead to much larger changes in $\mathrm{x}^{12}$ (as well as $x^{2}$ ) than in $x^{1}$. These changes have very different implications for the two countries' price levels.

32 With identical financial behavior in the two countries, $A^{i 1}+A^{i 2}=$ $\mathrm{B}^{1}+\mathrm{B}^{2}$; in addition, since asymmetries in size are ruled out, $\mathrm{y}_{0}^{1}=\mathrm{y}_{0}^{2}$. 
Country 2 finds that the mark depreciates substantially relative to both foreign currencies (for the case of a shift out of country 2's bonds); $\mathrm{X}^{2}$ rises while $\mathrm{X}^{12}$ falls. As a result, the mark prices of foreign goods from both the United States and country 1 rise in country 2 . With wages and prices free to vary in country 2 , the price of country $2^{\prime} s$ good also rises. So country $2^{\prime}$ s general price level rises.

Country 1 , in contrast, finds itself largely insulated from this disturbance. When domestic prices are fixed, the general price level in country 1 changes because of variations in $x^{12}$. But when prices can vary, the increase in the price of country 2 's good offsets the fall in $x^{12}$ so that the franc price of country 2's goods changes much less than when prices are fixed. 33 since in this case of high integration with the dollar market the change in $X^{l}$ is also small, country l's price level is largely insulated from this disturbance. 34 Introduction of the union must then increase the variance of its price level.

In the more general case where the financial markets of the member countries are integrated, country $I$ is not as fortunate. That country's price level can increase substantially in response to this disturbance in the absence of a union. Yet it is still tme that introduction of the union increases the variance of country l's price level still further.

33 It can be shown that $\mathrm{P}^{2}$ rises more than $\mathrm{x}^{12}$ falls, so that the franc price of country $2^{\prime}$ 's good actually rises, but by much less than the rise in $\mathrm{P}^{2}$.

34 In this case where the financial markets of the two member countries are well integrated only with the dollar market, the excess demand parameters in (20) below, $\mathrm{H}_{\mathrm{X} 2}^{1}$ and $\mathrm{J}^{12}$, which measure the cross effects on $\mathrm{H}^{1}$ of changes in $\mathrm{X}^{2}$ and $\mathrm{P}^{2}$, are both relatively small in absolute value. 
Consider, in turn, behavior under fully flexible rates and in the union. In this general case it is easy to show that the variance of $I^{l}$ is always smaller than the variance of $I^{2}$ under flexible rates. Compare the numerators in the expressions for $\sigma_{\mathrm{I} 1}^{2}$ and $\sigma_{\mathrm{I} 2}^{2}$ :

$$
\begin{aligned}
& \sigma_{\mathrm{I} I}^{2}=\left[\frac{\mathrm{H}_{\mathrm{x} 2}^{\mathrm{I}}-\mathrm{y}_{\mathrm{O}}^{2} \mathrm{~J}^{12}}{\mathrm{AC}}\right]^{2} \sigma_{\mathrm{h} 2,}^{2}, \\
& \sigma_{\mathrm{I} 2}^{2}=\left[\frac{-\mathrm{H}_{\mathrm{xl}}^{\mathrm{I}}+\mathrm{y}_{\mathrm{O}}^{\mathrm{I}} \mathrm{J}^{\mathrm{Il}}}{\mathrm{AC}}\right]^{2} \sigma_{\mathrm{h} 2,}^{2}
\end{aligned}
$$

Flexible Exchange Rates

where $C=\left[I-y_{0}^{I}\left(A^{11}+A^{12}\right)\right]\left[I-y_{0}^{I}\left(A^{11}-A^{12}\right)\right]>0$. Recall that $H_{x j}^{1}$ (for $j=1,2$ ) measures the response of the excess demand for $\mathrm{H}^{\mathcal{L}}$ to changes in exchange rates, while $\mathrm{J}^{l j}$ measures the direct and indirect response of this excess demand to changes in the level of transactions. Since the own effects predominate (i.e., $-\mathrm{H}_{\mathrm{xl}}^{\mathrm{I}}<\frac{\mathrm{H}}{\mathrm{x} 2}<0$ and $\mathrm{J}^{11}<-\mathrm{J}^{12}<0$ as previously indicated), the numerator of $\sigma_{\mathrm{I} I}^{2}$ must be smaller than that of $\sigma{ }_{\mathrm{I} 2}^{2}$.

It is also true that after the union is formed, the two countries share equally the effects of the disturbance. The variances of $I^{l}$ and $I^{2}$ can be written as: 35

$$
\sigma_{I 1}^{2}=\sigma_{I 2}^{2}=\left[\frac{\mathrm{H}_{\mathrm{x} 2}^{\mathrm{I}}-\mathrm{H}_{\mathrm{xl}}^{\mathrm{I}}-\mathrm{y}_{0}^{I} \mathrm{~J}^{12}+\mathrm{y}_{\mathrm{O}}^{\mathrm{I}} \mathrm{J}^{11}}{2 \mathrm{AC}}\right]^{2} \sigma_{\mathrm{h} 2}^{2} \frac{\text { Exchange-Rate }}{\underline{\text { Union }}}
$$

${ }^{35}$ The variance of either price level, in the union is:

$$
\sigma_{I i}^{2}=\left[\frac{\left(H_{x 2}^{I}-H_{x I}^{I}\right)}{2 A\left(I-y_{O}^{I}\left(B^{I}+B^{2}\right)\right)}\right]^{2} \sigma_{h 2}^{2} \text {. }
$$

Expression (2l) can be obtained by multiplying numerator and denominator by $\left(1-y_{0}^{l}\left(A^{11}-A^{12}\right)\right)$, then substituting $A^{11}+A^{12}=B^{l}+B^{2}$ and simplifying. 
As shown in Section I, the foreign exchange intervention associated with the union fixes the cross exchange rate between the franc and the mark, and as a result both currencies vary together relative to the dollar. With $\mathrm{P}^{1}$ and $\mathrm{P}^{2}$ exogenous as in section $\mathrm{I}$, the general price level of each of the member countries responds to the disturbance only to the extent that each country trades with the United States. With full indexation, in contrast, the rise in the domestic currency prices of U.S. goods induces adjustments in $\mathrm{P}^{1}$ and $\mathrm{P}^{2}$; both prices rise as much as the dollar exchange rates. Therefore, the franc and mark prices of goods from all three countries, and hence the general price levels, all rise by the same amount. (For that reason, under full indexation the variances of $I^{I}$ and $I^{2}$ do not depend upon the share of each good in either general price index.)

Now compare price behavior in the two systems. It is evident from (20) and (2l) that the variance of $I^{l}$ is raised by formation of the union, while the variance of $I^{2}$ is lowered. So with full indexation, countries $I$ and 2 fare quite differently by joining the union. The country experiencing the capital account disturbance gains markedly through the effect of the union in dispersing excess demand from its financial market to that of the other country.

How much the other country loses by joining the union depends upon how well integrated are the financial markets of the two countries. With financial ties largely confined to the dollar market, country 1 is largely insulated from this disturbance under flexible rates, so the loss in price stability in joining the union is greatest in this case. The more integrated the financial markets of the members, the less difference a union makes. Notice that these results are quite different from those in Section I 
where, in the case of high integration with the dollar market alone, the union was advantageous for country 1. When prices are fully indexed, higher integration with the dollar market makes the union even more undesirable for country 1. Thus, the degree of price indexation interacts in an important way with financial integration to determine the effects of the union on the individual countries.

C. Capital Account Disturbances in Both Countries

When capital account disturbances originate in the financial market of only one member country, an exchange-rate union disperses the effects of the disturbances to the financial market of the other member country. If both countries experience capital account disturbances, in contrast, there may not seem to be any benefits from union for either country. Yet if the disturbances in each market are not perfectly correlated, both member countries can benefit from a union.

Consider the case where the variances of the capital account disturbances in the two countries are equal: $\sigma_{h 1}^{2}=\sigma_{h 2}^{2}$. In this case, it can be shown that both member countries benefit from the union by reducing the variances of their general price levels as long as the disturbances are not perfectly correlated. ${ }^{36}$ By joining the union, the two countries gain from a diversification effect by which one disturbance is offset against another. This gain from diversification is greater the less well integrated are the financial markets of the two countries in the absence of a union. With a symmetrical rather than an asymmetrical pattern of disturbances, the

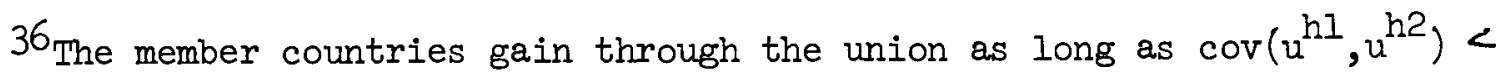
$\sigma_{h 1}^{2}=\sigma_{h 2}^{2}$. 
exchange rate union becomes once again beneficial to both cauntries.

\section{Conclusion}

This paper has focused on a number of important factors which determine the desirability of an exchange-rate union, including some factors which militate against joining a union:

1. How a union affects the individual members depends first of all on the types of disturbances experienced by the countries of the union. The title of the paper reflects the emphasis on one particular disturbance involving the financial markets of the United States and one member country. The volatility of the dollar exchange rate of that member country disrupts economic relationships between the two potential members of the union by changing cross exchange rates between member currencies.

2. Formation of the union fixes the cross exchange rate, but may introduce greater variation in the dollar exchange rate of the other member country. How changes in these exchange rates affect each country depends upon the share of trade within the union and with the outside world.

3. How each countryfares in the union also depends upon the degree of integration between the financial markets of the countries. Financial integration is important because it determines how exchange rates adjust to disturbances in the absence of a union.

4. Finally, the effect of the union depends upon the degree of wage and price indexation in the member countries. Price indexation interacts in a complex way with financial integration to determine the potential gains or losses of each country in joining the union. 
Under a variety of circumstances, these factors combine to make a union economically undesirable to one of the member countries, suggesting one of the reasons why many exchange-rate unions have thus far been unsuccessful. Much remains to be done in analyzing the effects of a union. But this paper has identified a number of factors upon which a decision to join a union should be based and has provided a framework for analyzing these factors. This framework, consisting of an asset market approach to exchange rates as well as wage and price equations to explain the interaction between prices and exchange rates, can be applied to analyze a variety of other types of behavior in an exchange-rate union. 


\section{Appendix: Explicit Solution of the Financial Model}

When the equilibrium conditions for the money and bond markets of countries 1 and 2 as given in Table 2 are linearized around their equilibrium values, the result is expression ( 1 ) in the text. The coefficients in this expression are given below with their expected signs: ${ }^{1}$

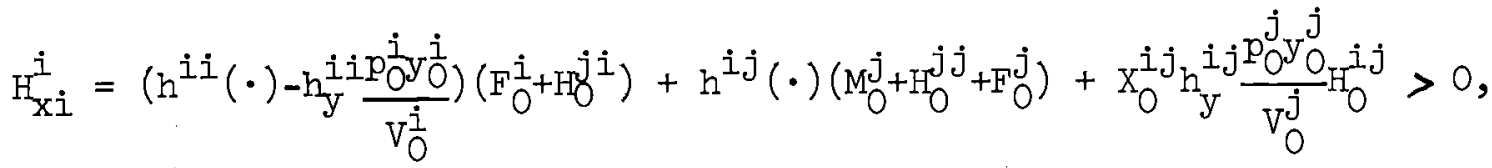

$$
\begin{aligned}
& H_{x j}^{i}=-\left(h^{i i}(\cdot)-h_{y}^{i i} \frac{p_{O}^{i} y_{0}^{i}}{v_{0}^{i}}\right) H_{0}^{j i}-h^{i j}(\cdot)\left(M_{0}^{j}+H_{0}^{j j}\right)-x_{0}^{i j} h_{y}^{i j} \frac{p_{O}^{j} y_{0}^{j}}{v_{0}^{j}}\left(F_{0}^{j}+H_{0}^{i j}\right)<0, \\
& J^{i i}=\left[\left(v_{O}^{i} h_{i}^{i i}+x_{O}^{i j} v_{O}^{j} h_{i}^{i j}\right) v_{O}^{j} m_{j}^{j}-\left(v_{O}^{i} h_{j}^{i i}+x_{O}^{i j} v_{O}^{j} h_{j}^{i j}\right) v_{O}^{j} m_{i}^{j}\right] \frac{m_{y}^{i}}{J}-h_{y}^{i i}<0, \\
& J^{i j}=\left[\left(v_{O}^{i} h_{j}^{i i}+x_{0}^{i j} v_{O}^{j} h_{j}^{i j}\right) v_{O}^{i} m_{i}^{i}-\left(v_{O}^{i} h_{i}^{i i}+x_{O}^{i j} v_{O}^{j} h_{i}^{i j}\right) v_{O}^{i} m_{j}^{i}\right]_{\frac{y}{J}}^{m_{j}^{j}}-x_{O}^{i j} h_{y}^{i j}>0, \\
& \text { and } J=v_{O}^{i} m_{i}^{i} v_{O}^{j} m_{j}^{j}-v_{O}^{i} m_{j}^{i} v_{O}^{j} m_{i}^{j}>0.2
\end{aligned}
$$

Because financial behavior in the two countries is assumed to be identical, $H_{x i}^{i}=H_{x j}^{j}, H_{x j}^{i}=H_{x i}^{j}, J^{i i}=J^{j j}$, and $J^{i j}=J^{j i}$.

IThe derivatives of the money demand functions in Table 2 are denoted by $\mathrm{m}_{\mathrm{J}}^{i}, \mathrm{~m}_{1}^{i}, \mathrm{~m}_{2}^{i}$, m for the four arguments of those functions, respectively; a similar notation is used for the bond demand functions.

${ }^{2} \mathrm{H}_{\mathrm{x} 2}^{\mathrm{I}}$ is assumed to be negative. This coefficient would be positive only if country 2 's demand for country $I^{\prime}$ 's bonds were unusually sensitive to increases in its wealth. A sufficient condition for a negative coefficient is that the wealth elasticity of country 2's demand for l's bonds be less than the ratio of total wealth to wealth held in foreign assets; that is,

$$
\left(\mathrm{h}^{12}(\cdot)-\mathrm{h}_{\mathrm{y}}^{12} \mathrm{P}_{0}^{2} \mathrm{y}_{0}^{2} / \mathrm{v}_{0}^{2}\right) \frac{\mathrm{v}_{0}^{2}}{\mathrm{~h}^{12}(\cdot) \mathrm{v}_{0}^{2}}<\frac{\mathrm{v}_{0}^{2}}{\left(\mathrm{x}_{0}^{2} \mathrm{~F}_{0}^{2}+\mathrm{H}_{0}^{12} / \mathrm{x}_{0}^{12}\right)}
$$

Note that the latter ratio has to be greater than unity. 


\section{References}

Allen, Polly Reynolds, Organization and Administration of a Monetary Union, Studies in International Finance No. 38, Princeton, June 1976.

Branson, William H., "Asset Markets and Relative Prices in Exchange Rate Determination," Seminar Paper No. 66, Stockholm, Institute for International Economic Studies, December 1976.

Branson, William H. and Rotemberg, Julio J., "International Adjustment with Wage Rigidity," NBER Working Paper Series No. 406, Cambridge, National Bureau of Economic Research, November 1979.

Corden, W.M., Monetary Integration, Essays in International Finance No. 93, Princeton, April 1972.

Dornbusch, Rudiger, "Expectations and Exchange Rate Dynamics," Journal of Political Economy, December 1976, 1161-1176.

Girton, Lance and Henderson, Dale, "Central Bank Operations in Foreign and Domestic Assets under Fixed and Flexible Exchange Rates," in P. Clark, et al., eds., The Effects of Exchange Rate Adjustments, U.S. Treasury, Washington, 1977.

Fischer, Stanley, "Wage Indexation and Macroeconomic Stability," in K. Brunner and A. Meltzer, Stabilization of the Domestic and International Economy, Vol. 5 of Carnegie-Rochester Conference Series on Public Policy. Amsterdam: North-Holland, 1977, 107-148.

Herring, Richard J. and Marston, Richard C., National Monetary Policies and International Financial Markets, Contributions to Economic Analysis No. 104. Amsterdam: North-Holland Publishing Co., 1977.

Gray, Jo Anna, "Wage Indexation: A Macroeconomic Approach," Journal of Monetary Economics, 2, April 1976, 221-235.

Henderson, Dale, "Modelling the Interdependence of National Money and Capital Markets," American Economic Review, 67, February 1977.

Ingram, James C., The Case for European Monetary Integration, Essays in International Finance, No. 98, Princeton, April 1973.

Marston, Richard C., "Cross Country Effects of Sterilization, Reserve Currencies, and Foreign Exchange Intervention," Journal of International Economics, February 1980, 63-78.

McKinnon, Ronald I., "Optimum Currency Areas," American Economic Review, 53, September 1963, 717-725. 
Modigliani, Franco and Padoa-Schioppa, Tommaso, The Management of an Open Economy with "100\% Plus" Wage Indexation, Essays in International Finance No. 130, Princeton, December 1978.

Mundell, Robert A., "A Theory of Optimum Currency Areas," American Economic Review, 51, September 1961, 657-665.

Sachs, Jeffrey, "Wage Indexation, Flexible Exchange Rates, and Macro-Economic Policy," International Finance Discussion Papers No. 137, Washington: Board of Governors, April 1979.

Thygesen, Niels, "The Emerging European Monetary System: Precursors, First Steps and Policy Options," 1979.

Tower, Edward and Willett, Thomas D., The Theory of Optimum Currency Areas and Exchange Rate Flexibility, Special Papers in International Economics No. 11, Princeton, May 1976. 